\title{
Investigating the extent to which mobile phones reduce Knowledge Transfer barriers in Student Project Teams
}

\author{
Authors: \\ Michael E. Kyobe ${ }^{1}$ \\ Mzwandile M. Shongwe \\ Affiliations: \\ ${ }^{1}$ Department of Information \\ Systems, University of Cape \\ Town, South Africa \\ Correspondence to: \\ Michael Kyobe \\ Email: \\ Michael.Kyobe@uct.ac.za \\ Postal address: \\ PO Box 34240, Rhodes Gift \\ 7707, South Africa

\section{Dates:} \\ Received: 25 May 2010 \\ Accepted: 28 June 2011 \\ Published: 17 Oct. 2011 \\ How to cite this article: \\ Kyobe, M.E. \& Shongwe, \\ M.M., 2011, 'Investigating \\ the extent to which mobile \\ phones reduce Knowledge \\ Transfer barriers in Student \\ Project Teams', SA Journal of \\ Information Management \\ 13(1), Art. \# 424, 10 pages. \\ doi:10.4102/sajim.v13i1.424
}

Group learning plays a key role in the transfer of knowledge. In institutions of learning, it enhances students' understanding, critical thinking, integration of knowledge and knowledge sharing. However, the transfer of knowledge in group projects is often impeded by factors such as time and budget constraints, individual and social barriers, and a lack of motivation.

Institutions of learning are increasingly adopting information and communication technologies (e.g. mobile technologies) to provide solutions to the challenges facing them. Whilst the integration of the mobile context and technologies in learning environment has been encouraged over the years, and indeed many students today can use mobile phones, the effectiveness of these technologies in reducing impediments to knowledge transfer in group learning has not been investigated.

This study investigated the extent to which mobile phones reduce the barriers to knowledge transfer in project groups. The impediments examined include the nature of knowledge, social barriers, lack of time and lack of motivation. Quantitative and qualitative approaches were used to collect and analyse the data. The sample consisted of 85 students engaged in group projects in the departments of Information Systems, Civil Engineering, Computer Science and Construction Engineering.

The results show that mobile phones reduce all four knowledge transfer barriers investigated in the project groups. We found no significant difference in the nature of knowledge shared by teams with weak and strong ties. This suggests that teams with weak social ties who normally experience difficulty sharing complex (tacit) knowledge can easily do so with the aid of mobile facilities. In addition, frequent users of mobile phones were motivated to share explicit knowledge with their peers whilst those who often work with tacit knowledge could convert it to explicit form and share it with others. Mobile features like short messaging service and multimedia messaging service (SMS \& MMS or what some people refer to as 'texting'), and email were mainly used to share knowledge and were perceived to reduce knowledge transfer time more than voice facilities.

Our findings indicate that most students do not utilise the affordances of mobile phones for tacit knowledge transfer. Sharing of tacit knowledge needs to be encouraged since it allows individuals to achieve personal goals and may lead to effective management of oneself, other people and tasks. In addition, students do not appear to recognise the role of mobile phones in enhancing knowledge transfer. More awareness of this role needs to be created in institutions of learning in order to improve group learning and student performance.

\section{Introduction}

Group learning plays a key role in the transfer of knowledge. In institutions of learning, it enhances students' understanding, critical thinking, integration of knowledge and knowledge sharing (Hammond \& Bennett 2002:55). However, the transfer of knowledge in group projects is often impeded by factors such as time and budget constraints, individual and social barriers, and lack of motivation (Ajmal \& Koskinen 2008:1; Fernie et al. 2003:180).

Institutions of learning are increasingly adopting information and communication technologies (e.g. mobile technologies) to provide solutions to the challenges facing them. Whilst the integration of the mobile context and technologies in the learning environment has been encouraged over the years (Benta, Cremene \& Padurean 2005:27; Sharples, Taylor \& Vavoula 2005:1), and indeed many students today can use mobile phones, the effectiveness of these technologies in minimising impediments to knowledge transfer in group learning has not been investigated. This study investigated the extent to which mobile phones reduce the barriers to knowledge transfer in project groups. 
In the following sections, literature on knowledge and knowledge transfer impediments is reviewed. This is followed by a review of collaborative and mobile learning theories. The contribution of mobile technology to knowledge transfer is examined and a research model is presented. The research methodology and analysis of findings are also presented in the following sections and finally conclusions are drawn.

\section{Literature review Knowledge transfer}

Knowledge transfer has been defined as the conveyance of knowledge from one place, person, or ownership to another (Major \& Cordey-Hayes 2000:591). Knowledge transfer is an important aspect of knowledge management (Sarker, Sarker \& Nicholson et al. 2003). Models explaining knowledge and its transfer are based mainly on two assumptions: the epistemological notion, which focuses on the nature of knowledge independent of its context and the ontological notion, which focuses on the relationship between knowledge and its environment or context independent of its nature (Moteleb \& Woodman 2007:56). According to Joshi, Sarker and Sarker (2007:323), there are three stances of the epistemological perspective, namely, (1) cognitivistic, (2) connectionistic and (3) autopoietic. They state that cognivitists view knowledge as a 'fixed and representable entity' that can be universally stored on media and easily shared by entities. By considering knowledge as universal, it means the characteristics of the sender, receiver or knowledge process rules are not critical and may not influence the knowledge transfer process. The connectionists do not consider knowledge to possess the universal characteristics. They consider it to be contextual and its transfer difficult therefore mechanisms such as social interactions, social ties or networks are needed to establish shared understanding. Advocates of the autopoietic perspective argue that knowledge is always created through an autonomous manner (i.e. by self production). They maintain that knowledge is always created (and not shared or transferred) and this is achieved through conversion processes such as socialisation, externalisation, internalisation and combinations thereof (Joshi et al. 2007).

In the present study, the researchers concur with Joshi et al. (2007:323) that none of the three epistemologies are inherently superior to the others. We believe that knowledge can exist in many different forms (e.g. explicit or tacit) and whilst there are challenges in the transfer of any form of knowledge, it is more problematic to manage or share tacit than explicit knowledge.

\section{Impediments to knowledge transfer in project- based or group learning}

Whilst many different knowledge transfer impediments have been identified in business organisations, little is still known about the impact of such impediments on the education sector and specifically in the project-based or group learning environment.
Project-based learning (PBL) is one example of collaborative learning whereby students pursue solutions to nontrivial problems by asking and refining questions, drawing conclusions, communicating their ideas and findings to others, and creating artefacts (Blumenfeld et al. 1991:371). Usually in this method of learning, teams rather than individual students work on a given project and support from teachers will often be substituted by interaction amongst team members (students). Students can, for instance, acquire presentation skills, time management skills, research skills and leadership skills (Disterer 2002:514). Studies conducted on group learning suggest however that willingness to transfer knowledge is often influenced by factors such as: the nature of knowledge, the strength of social ties between the parties, time pressure and motivation (Lightner, Benander \& Kramer 2008:64). These impediments are examined further in the following sections.

\section{Characteristics of the knowledge transferred}

Knowledge exists in two forms: tacit and explicit. Tacit knowledge is personal, context-specific, difficult to formalise, difficult to communicate, and to transfer due to its complexity (Hansen 1999:88). Explicit knowledge, on the other hand, can be articulated in formal language, duplicated and stored in databases or libraries. Sometimes the knowledge required may already exist in explicit form but due to syntactic and semantic problems it may not be accessible or comprehensive. One critical problem in education sectors is the absence of a technical vocabulary like the one used by doctors or lawyers. This makes codification difficult thereby forcing practitioners to retain their knowledge in tacit form (Foray \& Hargreaves 2003:8-9).

Research on knowledge transfer between project team members also reveals the difficulties created by the nature of knowledge. Fernie et al. (2003:178) argue that sharing tacit knowledge in projects is more complex because it is difficult to extract from the knower. Disterer (2002:514-515) identified that only a few organisations manage to integrate knowledge acquired in previous tasks into new projects because project knowledge is rarely captured or retained and often there is limited time between projects for new teams to conceptualise acquired skills.

\section{Time limitations}

Students often cite increased transaction costs (e.g. time spent scheduling and meeting as groups, negotiating differences of opinion) as overriding concerns about group projects. Such impediments leave limited room to share knowledge effectively. Kyobe (one of the authors of this article), who has supervised group projects at honours and post-graduate levels, has found that students often struggle to meet project deadlines and even after completing their projects they don't have sufficient time to evaluate or share knowledge gained from group projects. Lightner, Benander and Kramer (2008:61) confirm this and report that time pressure and the need to meet other obligations influence students' ability to transfer knowledge. Hansen (2006:15) also found that most 
semester-long projects take a considerable amount of time to manage.

\section{Social ties}

Disterer (2002:516) maintains that individual and social barriers exist in articulating and documenting individual knowledge thus making it difficult for project knowledge to be articulated and documented. He identified social barriers, such as lack of a common language to communicate knowledge, and special language features like analogies and metaphors to externalise tacit knowledge hidden in individual mental models, viewpoints and beliefs.

Fernie et al. (2003:177-187) highlight social network linkages as enablers of knowledge transfer in project teams. In social networks, actors in weak ties are usually not close friends. They consist of acquaintances that are loosely connected. Therefore, weak ties may discourage the development of longterm, frequent and sustained interactions similar to those found in groups with strong-ties. According to Strahilevitz (2004:35), strong ties tend to provide more social support than weak ties, in other words, emotional aid, companionship and a sense of belonging. Strahilevitz (2004:41) also states that sociologists have revealed that weak ties can rapidly spread gossip and news, and may not successfully transfer complex (e.g. tacit) knowledge. On the other hand information transmitted via strong ties generally spreads less quickly, but is more accurate and credible (Strahilevitz 2004:35-36). Blau (1974:623) observed that strong ties are more effective in small and closed social circles when trust exists.

\section{Motivation}

Schindler and Eppler (2003:334) identify a lack of motivation as a major impediment to knowledge transfer. Motivation may develop through incentives, image, social ties, power and trust. Jewels and Ford (2006:99) found that individuals will be motivated to share knowledge if they believe that it will contribute to team success and project practices.

\section{Information and Communication Technology in learning}

The term Information and Communication Technology (ICT) covers any product or products that can store, retrieve, manipulate, transmit or retrieve information electronically in a digital form. These technologies have revolutionised learning, resolving some of the knowledge sharing problems that were outlined earlier in the article but also creating new challenges for institutions (Calongne 2008). On the one hand, ICT has provided a wealth of knowledge to many learners, and improved the speed and style of learning thereby enhancing understanding. There is increasing evidence of how ICT has bridged the gaps in education between the less and more privileged learners, and provided opportunities for learners and educators to present their skills in a variety of ways. On the other hand, research shows that these developments have also contributed to some setbacks in learning such as: a loss of communication skills and interactive abilities between students and teachers, and distractions in the classroom as a result of the use of the Internet, computer games and email. In addition, where technologies are not fairly distributed, the gaps in understanding between those who possess it and those who do not may be widened.

Despite these limitations, many writers maintain that the benefits derived from the adoption of ICT in education outweigh the limitations (Hattangdi \& Gosh 2008; Calongne 2008). In the present study, the researchers examine the use of one form of ICT (i.e. the mobile phone), in facilitating knowledge transfer in group projects. Most students use mobile phones today and their contribution to education has already been established (Benta et al. 2005; Sharples et al. 2005). However, limited studies have examined the extent to which these tools could be used to minimise the impediments to knowledge transfer in project groups. The major strength of the mobile phone compared to other ICT is its ubiquitous nature (Ahmad \& Mentor 2010). Unlike other ICT (computers, PDAs etc.) mobile phones are flexible, and accessible to most students. This notion is shared by Cheung (2005) who states that unlike other mobile devices such as PDAs mobile phones are accessible to most students.

\section{Mobile learning and the contribution of mobile technology to knowledge transfer}

Mobile learning is an example of collaborative learning adopted by institutions today. Sharples et al. (2005:8) define mobile learning as 'a labile process of "coming to know" through conversation in context, by which learners in cooperation with peers and teachers construct transiently stable interpretations of their world'. In his 'Framework for the Rational Analysis of Mobile Education' (FRAME), Koole (2009:25) describes mobile learning as a process resulting from the convergence of mobile technologies (e.g. physical, technical and functional characteristics), human learning capabilities (e.g. the learner's cognitive abilities, memory, prior knowledge, emotions and possible motivations), and social interaction (e.g. conversation and cooperation rules, agreement on the meaning of signs and symbols, cultural beliefs, etc.).

Kooles maintains that mobile learning experiences exist within a context of information. He shows that by working collectively and individually, facilitated by technology, learners interact with information by 'consuming and creating it'. Through such interaction, information becomes meaningful and useful to them.

Pousttchi, Weizmann and Turowski (2003:414) illustrate how mobile technology can facilitate communication and knowledge sharing in their Mobile Added Values (MAV) theory. They argue that added value in the use of mobile communication technology is obtained through its ubiquity, context-sensitivity, identifying functions, and command and control functions. 'Ubiquity' has been defined as the ability to send and receive data anytime and anywhere. This means that spatial and temporal restrictions to knowledge creation and transfer are resolved. 'Context-sensitivity' 
may be defined as the delivery of customised products or services fitting the particular needs of the user in his or her current situation (Derballa \& Pousttchi 2004:586). This is enabled through mechanisms such as personalisation, interactivity and location determination using tools such as mind-maps. 'Identifying functions' relate to the ability to authenticate the subscriber as well as the devices used. Context-sensitivity and identifying functions act as support factors. They facilitate the documentation of the knowledge creation process. With these functions, it becomes possible to gather information about how the context knowledge was created and characteristics of participating users (Derballa \& Pousttchi 2004:586-587).

The aim of the present study is to examine the extent to which mobile phones reduce knowledge transfer barriers in group projects. In the following section, we discuss mobile phone characteristics that enable value creation in the three areas outlined in the MAV model and show how these may reduce knowledge transfer impediments.

\section{Mobile phones features and value added services}

Mobile phones are devices that support mobile learning through voice (sound), text and graphics (Benta et al. 2004:27). Mobile phone technologies have been available since the 1980s and are currently in their third generation. The current generation provides various value added services and features such as:

- receive more information

- use SMS text

- MMS

- email

- voice mail

- Internet access

- streaming radio and television

- 3G

- WiFi technologies.

Prensky (2004:1-6) and Benta et al. (2004:27) have identified the following services and features to be particularly important in supporting learning and knowledge transfer:

- voice

- SMS

- graphics

- user controlled operating systems

- 'downloadables'

- browsers

- camera functions

- geopositioning.

An in-depth analysis of the m-learning literature reveals that two mobile phone services are widely used in mobile learning: SMS and MMS. A brief discussion of the two services is given in the following sections.

\section{Messaging services (SMS and MMS)}

Mobile phones offer a number of text messaging services. The short messaging service (SMS) and the multimedia messaging service (MMS) are the most common since they provide a simple and affordable way to communicate. SMS is available on most mobile phones. It is a service that allows the sending of short messages known as SMSes, between mobile phones and other handheld devices. MMS on the other hand enables the composition and sending of messages with one or more multimedia parts. That is photos, video and audio messages (Wagner 2005). These services (MMS \& SMS) have been used extensively for learning purposes (see Nonyongo, Mabusela \& Monene 2005; Mellow 2005; Benta et al. 2004). They are basically used to transfer explicit knowledge.

Other services that we believe could support knowledge transfer and m-learning are voice technologies, Internet browsers and GPS. Voice technologies can enable the transfer of tacit knowledge. According to Nonaka (1995), tacit knowledge can be transferred through the process of socialisation. Conversations using voice facilities are social processes for eliciting, unpacking, articulating, applying and contextualising knowledge. Students can use voice mail to interact with persons in a group whose knowledge and expertise is important.

Internet Browsers are other important features that can support knowledge transfer. 3G enabled mobile phones have the ability to browse the Internet. Having a browser in the cell phone enables students to access the Internet. That means they can access all Internet resources from their phones. We also believe that the Global Positioning System (GPS) can minimise impediments of the source of knowledge. GPS is 'a satellite navigation system used for determining one's precise location and providing a highly accurate time reference almost anywhere on earth' (Wagner 2005:46). Students can use their mobile phones to get information about wherever they are - in the city, campus, countryside, and township or in the bush. This technology has clear applications in geography, archaeology, architecture, mathematics, science and other subjects. Students studying nature, architecture, art or design can search for images on the web that match what they find in life in order to understand their properties (Prensky 2004:5).

Messaging services can enhance the ability to receive knowledge. This ability is influenced by lack of motivation, lack of absorptive capacity and knowledge retention (Szulanski 1996). Lack of absorptive capacity and retention (for instance) is the inability to recognise the value of new information, assimilate it and apply it to practical ends. This is usually caused by ignorance, lack of prior knowledge and in most cases lack of a common language between the provider and recipient of knowledge. Students develop various communication styles when using messaging services. With this communication styles, they can verbalise rules, terminology and descriptions and create technical vocabularies that support the codification of knowledge.

\section{Summary of literature review}

Researchers show that there are impediments to knowledge transfer in project teams (Disterer 2002; Schindler \& Eppler 2003). For the purposes of the study four impediments are 
examined: the nature of the knowledge transferred (tacit or explicit), social ties, time, and motivation. Evidence provided in the previous sections suggests that mobile phones can reduce many of these barriers and improve knowledge transfer. A research model representing these relationships is shown in Figure 1.

\section{Research model}

Figure 1 represents our research model. We argue that when students use mobile phones during their group tasks, knowledge transfer impediments will be reduced leading to improvement in group performance. Hypothesis 1, Hypothesis 2, Hypothesis 3 and Hypothesis 4 represent the four propositions about the relationships between the elements of this model. These propositions are stated in the following section.

\section{Propositions}

Social ties barriers can prevent the articulation and documentation of individual knowledge (Liao et al. 2004:24). Under normal circumstances, we expect students who group themselves to have some strong social ties while those grouped randomly by the teacher to possess weak social ties. The latter will transfer less knowledge due to potential lack of social support and sometimes trust (Fernie et al. 2003; Strahilevitz 2004). However, if this latter group uses mobile phones, they should be able to share complex (e.g. tacit) knowledge like those with strong ties. We therefore hypothesise that:

- Hypothesis 1: In a mobile phone supported project, there will be limited differences between the nature of knowledge shared by individuals with weak and strong social ties.

Students are often concerned about time spent scheduling and meeting as groups to discuss or evaluate findings. Features of mobile phones such as voice, SMS and text-based chat support the recording and receiving of messages at anytime. Students can read and respond to messages at their convenience, can easily codify knowledge using knowledge maps thereby speeding up understanding.

Furthermore, project teams are usually temporal. They are disbanded after finishing their respective projects. Students often join other classes or institutions without maintaining close contacts thereby taking their experiences away with them. Locating previous team members to share or seek knowledge may be time consuming and difficult thereby impeding the transfer of knowledge (Schindler \& Eppler 2003).

A mobile phone can overcome such barriers to knowledge transfer. It can be used to share tacit knowledge retained by former team members who may now be dispersed. The ability of the mobile phone to be ubiquitous can help students to overcome this impediment to knowledge transfer (Derballa \& Pousttchi 2004). This reduces reaction time and ensures convenience during knowledge sharing, hence:

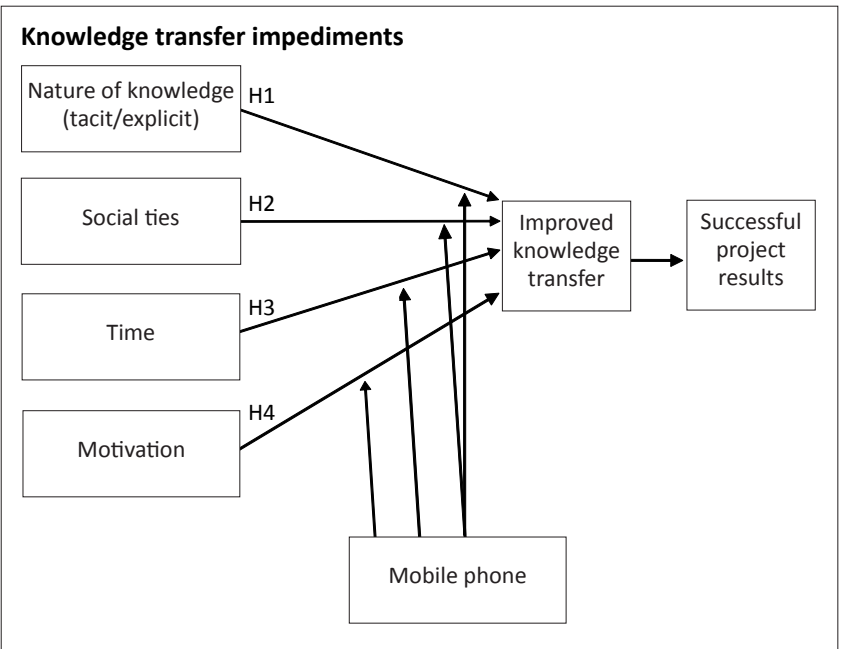

$\mathrm{H} 1$, Hypothesis $1 ; \mathrm{H} 2$, Hypothesis $2 ; \mathrm{H} 3$, Hypothesis $3 ; \mathrm{H} 4$, Hypothesis 4.

FIGURE 1: The role of mobile phones in reducing knowledge transfer impediments in team projects.

- Hypothesis 2: In a mobile phone based project, students who use features such as voice, chat and SMS will transfer knowledge in less time than those who do not.

Lack of motivation affects the smooth transfer of knowledge. Jewels and Ford (2006) found that individuals will be motivated to share knowledge if they believe that it will contribute to team success and project practices.

A mobile phone provides features that enhance understanding (knowledge maps, easy navigation and operation features, codification, etc.) thereby building confidence in the project progress (Pollack 2006). Understanding also makes it possible for students to participate in on-line discussions and also to share more information and knowledge. We therefore hypothesise that:

- Hypothesis 3: In a mobile phone based project, students who use mobile phones more often will be more motivated to share knowledge with their peers than those that do not.

It is expected that students who develop knowledge through experimental probes and strong feedback loops will disseminate knowledge much more easily than those who deal with knowledge that is more tacit in nature ( $\mathrm{Li} \& \mathrm{Gao}$ 2003). However, where mobile phones are used, there will be limited difference in the nature of knowledge transferred by these two categories of students (e.g. science and humanities students). Mobile phones allow easy access to information and have features like SMS and MMS that can support codification of tacit knowledge (Lindquist et al. 2007). Students develop technical vocabulary when using mobile phones (just like doctors or lawyers), thereby addressing the syntactic and semantic problem. These features make transfer of tacit and explicit knowledge possible thereby minimising the impediments posed by the nature of knowledge transferred. We therefore hypothesise that:

- Hypothesis 4: In a mobile phone based project, students dealing with knowledge that is more tacit in nature will be able to transfer it easily. 


\section{Research methodology}

The study was informed by the positivist philosophy (Olikowsky \& Baroudi 1991). A case study approach (Myers 1997) was adopted to examine knowledge transfer problems at a South African University. The researchers adopted both quantitative and qualitative methods to collect and analyse data. Stratified sampling (Blaikie 2010; Walliman 2006) was adopted to select respondents from the population. The population was university students who performed the projects. Four strata from the departments of Information Systems, Computer Science, Civil Engineering and Construction Economics and Management were selected. Respondents were then sampled from these strata. These departments were specifically selected because students conduct team projects and the knowledge they share varies from tacit to explicit depending on their disciplines. A questionnaire consisting to both open and closed ended questions was developed and administered to the students. In addition, follow-up interviews were also conducted with students from these departments. The respondents consisted of both undergraduate and postgraduate students.

\section{Profile of the Project Groups Group A}

Group A consisted of 15 students from the Construction Economics and Management department. This was a combination of two courses: New Venture Planning and Professional Communication Studies. In these courses students were divided into teams of four. The students were required to design, prepare and present a business plan at the end of the semester. They started by brainstorming ideas and sharing knowledge about the whole project. This involved identification and research on the chosen idea (i.e. carrying out concept analysis, customer analysis, market analysis, and financial analysis). This was done in a space of five to six weeks. The group also had to produce a poster advertising the business idea and make a presentation to the whole class. This group mentioned that they had conducted a lot of construction related projects in their department. Their responses were therefore based on past and present experiences.

\section{Group B}

Group B consisted of 20 Civil Engineering third year students. The course was designed to introduce students to the dynamics of both urban transportation and human settlement. The students had to work in teams of five. They investigated the implementation strategies employed by city municipalities and government bodies to provide an environmentally friendly and efficient transport system.

\section{Group C and Group D}

These consisted of 35 students majoring in Information Systems (group C) and 15 in Computer Science (group D). The project tested students' knowledge of systems development, programming and project management concepts. Students were required to develop a business solution whereby practical and theoretical competences in the aforementioned areas were assessed.

\section{Research instrument}

A survey questionnaire used in a previous study conducted by one of the authors was adapted. The questionnaire consisted of five sections. Section A collected data on the respondent demographics and social ties. Section B captured data on the use of mobile phones, section $C$ on the student's motivation and section $\mathrm{D}$ on knowledge transfer time. The final section E collected data on the success of the student's project. Open-ended questions were used in some sections in order to collect students' views about the nature and type of knowledge and other issues investigated. The instrument was piloted with three academics and five students and adjustments were made to some questions.

Prior arrangements were made with the lecturers to administer the questionnaires at the end of the lectures. This allowed us an opportunity to involve as many students as possible in the study and to give students an opportunity to seek clarity on issues relating to the questionnaire. Students were given about 10 minutes to complete the questionnaire.

\section{Data analysis Descriptive data}

Data were analysed using a statistical package (Statistica 8.0). There were 50 male students and 35 female students. Of these 40 were African (Black), 15 White and 30 Indian and Coloured students. The respondents from Information Systems were (35), Computer Science (15) Civil Engineering (20) and Construction Economics and Management (15).

Students were asked to indicate their years of experience in using mobile phones, the purpose for which they use the phone and the features on their phones. User experience refers to how people use interactive products and this may affect the way they interact with the devices and share knowledge according to Roto (2006). In the present study, user experience was measured by the number of years a respondent has been using a mobile phone $(1=$ less than a year, $5=$ more than four years). Mobile phones had been used by $82 \%$ for more than four years. The results are presented in Tables 1-3.

These results indicate that most respondents had the basic knowledge to use mobile phones (average usage experience exceeds 4 years) and had similar phone features (e.g. video,

\begin{tabular}{lccc}
\multicolumn{4}{l}{ TABLE 1: Mobile phone usage experience. } \\
\hline Group & Number & Mean & Standard deviation \\
\hline Information systems & 35 & 5 & 0.61 \\
Computer Science & 15 & 5 & 0.54 \\
Civil Engineering & 20 & 5 & 0.31 \\
Economic \& Construction & 15 & 5 & 0.77 \\
Engineering & & & \\
\hline
\end{tabular}


email, MMS, camera, speak phone, Internet, SMS and voice). The results also suggest that entertainment is the most common reason why students use mobile phones.

\section{Reliability test Reliability}

The Cronbach Alpha results in Table 4 indicate a good measure of internal validity for some variables. Nature of knowledge and social ties scored above the threshold of 0.70 (Hair et al. 2006:137) whilst success, time and motivation scored slightly below the threshold. This could be attributed to the fact that only a few items were used to measure these three constructs. We, however, decided to use these items since the scores were very close to 0.70 .

\section{Social ties}

In order to investigate the impact of social ties on knowledge transfer in a team project using mobile phones, the respondents were required to indicate who allocated them to project teams and the criteria used. It was expected that students who grouped themselves on the basis of friendship have closer social ties. The results indicate that students from Computer Science, Information Systems and Construction Economics departments allocated themselves to project teams and that friendship was used as a criterion. Students from Civil Engineering were grouped by their lecturer. Many did not know the criteria used by the lecturer. The results are presented in Table 5.

Since some students did not know the criterion for allocation, the distinction between those with weak and strong ties was based on who allocated them to different teams. Those who allocated themselves were considered to possess strong ties since they knew each other whilst those allocated by the lecturer may have not had much in common and as such had weak ties.

Table 6 represents a summary of responses to the questions that measured the extent to which mobile phones were used to share knowledge, motivated students to engage in knowledge sharing and saved time during this process. A scale of 1 (indicates that the student strongly disagrees) to 5 (indicates that the student strongly agrees) was used.

\section{Social ties and knowledge sharing}

The average score of students with strong ties on items B1-B8 was 4.32 whilst that of students with weak social ties was 4.09 . These results suggest limited differences in the usage of mobile phone features hence, the nature of knowledge shared by the two groups. Both groups agreed that mobile phones were used for knowledge sharing. A Chi-square test was conducted which also confirmed that the difference in these results was not significant (Chi-square $=2.77, p=0.175)$.

Hypothesis 1 is therefore supported. Mobile phones can enable increased knowledge transfer and sharing of complex
TABLE 2: Features on student mobile phones.

\begin{tabular}{lc}
\hline Mobile phone feature & $\mathbf{\%}$ \\
\hline Chatting & 56 \\
GPS & 20 \\
Word processing & 3 \\
Video calling & 6 \\
Bluetooth & 20 \\
Live TV & 8 \\
Video & 64 \\
Email & 88 \\
MMS & 92 \\
Camera & 96 \\
Speak phone & 94 \\
Internet & 92 \\
SMS & 100 \\
Voice & 100 \\
\hline
\end{tabular}

TABLE 3: Purpose for which the mobile phone is used.

\begin{tabular}{ll}
\hline Purpose & $\mathbf{\%}$ \\
\hline Academic & 58 \\
Entertainment & 84 \\
Communication & 64 \\
Social purposes & 52 \\
\hline
\end{tabular}

Social purposes

TABLE 4: Reliability scores.

\begin{tabular}{lc}
\hline Variable & Alpha score \\
\hline Nature of knowledge & 0.74 \\
Social ties & 0.72 \\
Motivation & 0.69 \\
Time & 0.68 \\
Success & 0.68 \\
\hline
\end{tabular}

Table 5: Basis for allocation to project teams.

\begin{tabular}{lcc}
\hline Group & Allocated by & Criterion \\
\hline Civil Engineering & Lecturer & Do not know \\
Computer Science & Themselves & Friendship \\
Construction Economics & Themselves & Friendship \\
Information Systems & Themselves & Friendship \\
\hline
\end{tabular}

TABLE 6: Use of mobile phone features, motivation of users to share knowledge and saving of knowledge transfer time.

\begin{tabular}{|c|c|c|}
\hline Mobile phone features & Mean & Standard Deviation \\
\hline \multicolumn{3}{|l|}{ Item } \\
\hline B1 - I use SMS/MMS & 4.61 & 0.98 \\
\hline B2 - Group mates use SMS/MMS & 4.91 & 1.22 \\
\hline B3 - I email project ideas to group mates & 3.73 & 1.05 \\
\hline B4 - Group mates email project ideas to me & 3.56 & 0.94 \\
\hline $\begin{array}{l}\text { B5 - Our project group has used video } \\
\text { conferencing }\end{array}$ & 2.05 & 1.34 \\
\hline B6 - I usually call group mates to share ideas & 2.47 & 1.07 \\
\hline B7 - Our group has used push-to-talk facility & 1.93 & 0.88 \\
\hline $\begin{array}{l}\text { B8 - I have used speak-phone features to } \\
\text { share ideas }\end{array}$ & 1.59 & 0.82 \\
\hline $\begin{array}{l}\text { B9-Intend to use my phone for knowledge } \\
\text { transfer in future }\end{array}$ & 4.69 & 0.94 \\
\hline \multicolumn{3}{|l|}{ Motivation } \\
\hline $\begin{array}{l}\mathrm{C} 1-\text { I encourage others to share ideas using } \\
\text { their phones }\end{array}$ & 3.65 & 1.32 \\
\hline $\begin{array}{l}\mathrm{C} 2 \text { - My group members are confortable } \\
\text { sharing ideas over the phone }\end{array}$ & 3.59 & 0.84 \\
\hline $\begin{array}{l}\text { C3 - Mobile phones are necessary for } \\
\text { sharing ideas when physically apart }\end{array}$ & 4.02 & 0.99 \\
\hline \multicolumn{3}{|l|}{ Time } \\
\hline $\begin{array}{l}\text { D1 - Mobile phones enable sharing ideas in } \\
\text { a shorter time }\end{array}$ & 3.87 & 0.87 \\
\hline $\begin{array}{l}\text { D2 - Knowledge acquired previously can be } \\
\text { access in a shorter time using mobile phones }\end{array}$ & 3.34 & 1.23 \\
\hline $\begin{array}{l}\text { D3 - It takes less time to share knowledge } \\
\text { using voice facilities }\end{array}$ & 2.93 & 1.04 \\
\hline $\begin{array}{l}\text { D4 - It takes less time to share knowledge } \\
\text { using SMS and MMS }\end{array}$ & 3.99 & 0.87 \\
\hline
\end{tabular}

using SMS and MMS

$B$, data on the use of mobile phones.

C, data on the student's motivation.

D, data on knowledge transfer time. 
knowledge in groups with weak ties. This is consistent with Palen's (2002) earlier observation that mobile phones in social networks increase access and relevance of membership in a network of social relationships thereby minimising impediments due to social ties.

\section{Time}

Items D1-D4 (in Table 6) show the respondents' perception of the time saving capabilities of mobile phones. The results indicate that students who use mobile phone features like SMS, MMS and email take less time to transfer knowledge and also to acquire knowledge from previous projects than those using voice facilities. There is therefore a relationship between time saving and the use of mobile phones. This is also confirmed by the significant association between D4 (time saving using SMS and MMS) and B1 and B2 (usage of SMS and MMS) as shown in Table 7. Knowledge transfer using voice was perceived to take longer by most respondents. This is perhaps due to the fact that students don't use voice facilities effectively. They most likely store messages and never retrieve them.

Results of a correlation analysis (see Table 7) revealed a significant positive association (+0.34) between SMS and MMS usage (B1) and D4 (time saving using SMS and MMS). There is also a significant negative association $(-0.12)$ between B1 and D3 (time saving using voice facilities). This suggests that even those who often make phone calls or make use of voice facilities find SMS and MMS less time consuming. However, no significant association exist between B8 (usage of speaker-phone features) and D3 (time saving using voice facilities) and also between B8 and D4 (time saving using SMS/MMS). Hypothesis2 is therefore partially supported. Knowledge is transferred in less time only where SMS, MMS and email are used.

\section{Motivation to share knowledge}

Students were asked to indicate whether mobile phones motivated them to share knowledge (see Table 6, C1-C3). The researchers compared the frequency of mobile phone usage (B1, B3 and B6) with mobile phone motivation (C1, C2, C3 and $\mathrm{B} 9$ ). Those who used mobile phones less frequently (e.g. mean score for B1, B3, B6 less than 4.00) were not motivated to share knowledge using mobile phones (e.g. mean score for C1, C2, C3, B9 less than 4.00). Table 7 shows a significant association between items (B1 and $\mathrm{C} 1$, and also between B3 and C3). Hence hypothesis 3 was supported since those who used mobile phones frequently were motivated to share knowledge with peers.

Items B1-B8 (see Table 6) also captured the nature of knowledge transferred by the students. SMS, MMS, email, and graphics messages are considered to be explicit in nature. Discussions over the phone usually involve the transfer of tacit knowledge especially when no record of the interaction is codified. The results suggest that most teams (in all groups studied) transfer their knowledge by SMS, MMS and email. Voice messaging, voice recording and use of language facilities are not commonly used.

Respondents were asked to comment on the type of knowledge shared and give the specific phone features used to achieve this. Follow-up interviews were conducted with eight students who indicated their willingness to be interviewed further. We found that most students mainly use text-based features, which suggests that mobile phones are mainly used for the transfer of explicit knowledge. Students in the humanities who deal with more tacit knowledge also frequently use features like MMS, SMS and email to share knowledge. They therefore leverage mobile technology to convert their tacit knowledge to explicit forms. Hypothesis 4 was therefore supported.

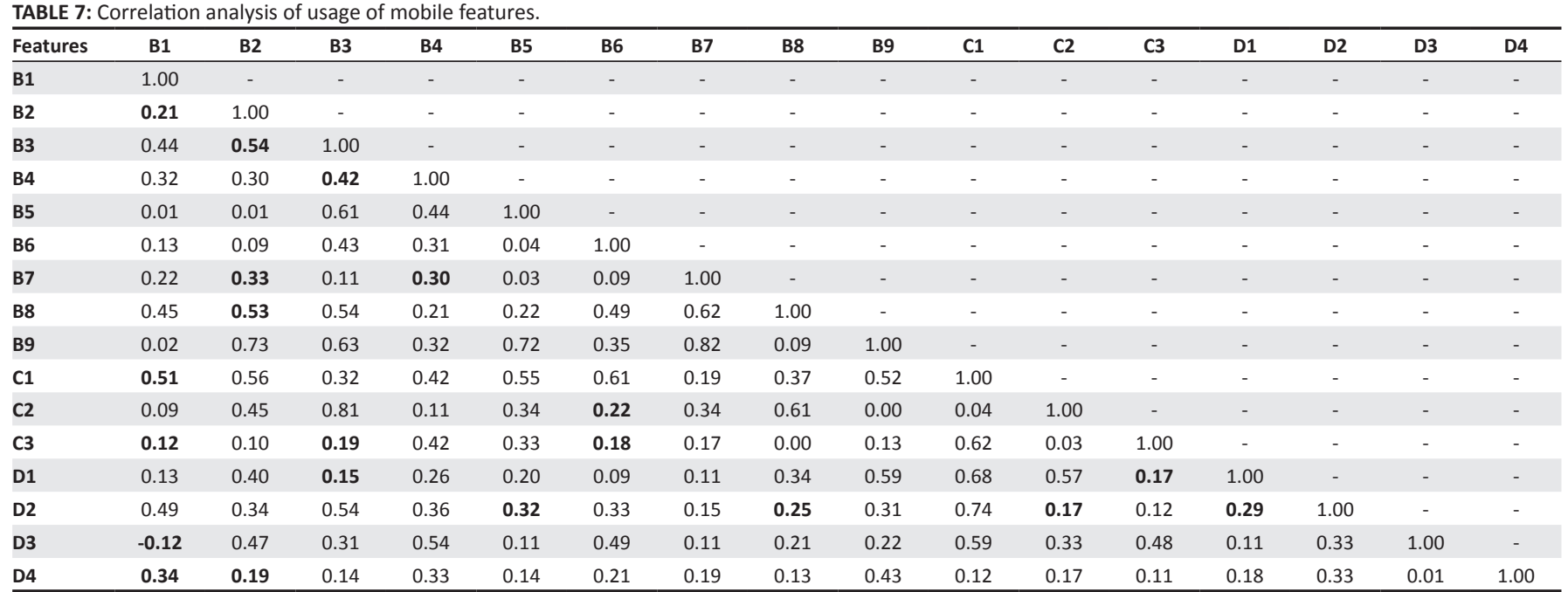

Note: correlation coefficients in bold are significant at $p<0.05$.

$B$, data on the use of mobile phones.

$C$, data on the student's motivation.

D, date on knowledge transfer time. 


\section{Project success}

Students were required to indicate their project success in order to determine the extent to which mobile phones influenced project success. Those who had finished their projects were required to indicate their final marks while those who had not, rated their progress on a scale of $50 \%$ $-100 \%$. Table 8 presents the results of the completed projects.

The results indicate that teams from Civil Engineering and Construction Economics obtained between $61 \%$ - 70\% in their projects results, Computer Science teams obtained $50 \%-60 \%$ whilst Information Systems teams obtained (70\% - 80\%). Many students did however not acknowledge the contribution of mobile phones to the success of their projects. Only $37 \%$ of the respondents linked their success to the use of mobile phones.

\section{Conclusion}

This study investigated the role of mobile phones in reducing knowledge transfer barriers caused by social aspects, the nature of knowledge, a lack of time, and a lack of motivation. Contrary to earlier literature (Fernie et al. 2003; Strahilevitz 2004), we found no significant difference in the nature of knowledge shared by teams with weak and strong ties. This suggests that teams with weak social ties which normally experience difficulties in sharing complex knowledge can resolve this problem by adopting mobile technologies. The study also confirms that mobile phones enable codification of tacit knowledge and motivates knowledge sharing with peers. We however found that time barriers to knowledge transfer are perceived to be reduced only when knowledge is conveyed in explicit form (e.g. using SMS, MMS and email) than in tacit form (e.g. voice messages, phone calling, etc.).

The fact that most students in this study did not utilise the affordances of mobile devices for tacit knowledge transfer raises much concern. Sternberg et al. (1995) argue that tacit knowledge allows individuals to achieve personal goals, job success and better performance. They add that it leads to effective management of oneself, other people and tasks. This suggests therefore that the sharing of tacit knowledge is beneficial to the learners not only in school but also in the industry. The present study did not investigate this issue in more detail during the interviews and these followup interviews only involved eight respondents, therefore caution needs to be exercised when generalising some of the findings. Future studies involving larger samples of learners should be conducted to examine the role of tacit knowledge in mobile learning and its impact on student performance.

TABLE 8: Results of completed projects.

\begin{tabular}{lcc}
\hline Group & Results & Comments \\
\hline Civil Engineering & $61-70$ & Good \\
Computer Science & $50-60$ & Fair \\
Construction Economics & $61-70$ & Good \\
Information Systems & $71-80$ & Very Good \\
\hline
\end{tabular}

Results are given as percentage.

\section{References}

Ahmad, N. \& Mentor, D., 2010, Mobile Learning: An Introduction, viewed 15 June 2011, from http://www.studyplace.org/w/images/9/9f/Mobile_Phone_ Learning_Syllabus_Spring_2010.pdf

Ajmal, M.M. \& Koskinen, K.U., 2008, 'Knowledge transfer in Project-Based Organisations: An Organisational Culture Perspective', Project Management Journal 39(1), 7-15.

Benta, K.L., Cremene, M. \& Padurean, R., 2005, 'Multimedia m-learning using mobile phones', in J. Attewell \& C. Smith-Savill (eds.), Mobile Learning Anytime Everywhere: A Book of Papers from MLEARN 2004, pp. 27-28, Learning and Skills Development, London, UK, viewed 12 January 2008, from http://elearning. typepad.com/thelearnedman/mobile_learning/reports/mLearn04_papers.pdf

Blau, P., 1974, 'Parameters of Social Structure', American Sociological Review 39(5), 615-35.

Blumenfeld, P.C., Soloway, E., Marx R.W., Krajcik, J.S., Gudzdial, M. \& Palincsar, A., 1991, 'Motivating Project Based Learning: Sustaining the Doing, Supporting the Learning', Educational Psychologist 26 (3 \& 4), 369-398.

Calongne, C., 2008, 'Educational Frontiers: Learning in a Virtual world', Educause review 43(5) Sept/October.

Cheung, S.L., 2005, 'Using Mobile Phone Messaging as a Response Medium in Classroom Experiments', Journal of Economic Education 39(1), 51-67.

Derballa, V. \& Pousttchi, K., 2004, 'Extending Knowledge Management to Mobile Workplaces', paper presented at the International Conference on Electronic Workplaces', paper presented at the International Conference
Commerce, Delft, Netherlands, October 25-27, 2004, pp. 583-590.

Disterer, G., 2002, 'Management of Project Knowledge and Experiences', Journal of Knowledge Management 6(5), 512-520.

Fernie, S., Green, S.D., Weller, S.J. \& Newcomb, R., 2003, 'Knowledge Sharing: Content, Confusion and Controversy', International Journal of Project Management 21, 177-187.

Foray, D. \& Hargreaves, D.H., 2003, 'The production of knowledge in different sectors: A model and some hypothesis', London Review of Education 1(1), 7-19.

Hair, J.F., Black, W.C., Babin, B.J., Anderson, R.E. \& Tatham, R.L., 2006, Multivariate Data Analysis, 6th edn., Pearson Prentice Hall, New Jersey, NJ.

Hammond, N. \& Bennett, C., 2002, 'Discipline differences in role and use of ICT to support group based learning', Journal of Computer Assisted Learning 18(1), 55-63.

Hansen, M.T., 1999, 'The search-transfer problem: The role of weak ties in sharing knowledge across organization subunits', Administrative Science Quarterly 44(1), 82-111.

Hansen, R.S., 2006, 'Benefits and Problems With Student Teams: Suggestions for Improving Team Projects', The Journal of education for business 82(1), 11-19.

Hattangdi, A. \& Gosh, A., 2008, Enhancing the quality and accessibility of higher education through the use of Information and Communication Technology, viewed 13 August 2010, from http://www.iitk.ac.in/infocell/announce/convention/ papers/Strategy\%20Learning-01-Ashish\%20Hattangdi,\%20\%20Atanu\%20Ghosh. pdf

Jewels, T. \& Ford, M., 2006, 'Factors influencing Knowledge sharing in Information Technology project', E-service Journal 5(1), 99-117.

Joshi, K.D., Sarker, S. \& Sarker, S., 2007, 'Knowledge transfer within information systems development teams: Examining the role of knowledge source attributes', Decision Support Systems 43 (2), 322-335.

Koole, M., 2005, 'A model for framing Mobile Learning', in M. Alley (ed.), Mobile Learning: Transforming the Delivery of Education and Training: Library and Archives Canada Cataloguing in Publication, pp. 26-47, Athabasca University Press, Athabasca, AB.

Li, M., \& Gao, F., 2003, 'Why Nonaka highlights Tacit Knowledge: a Critical Review', Journal of Knowledge Management 7(4), 6-14

Liao, S-H., Chang, J-C., Cheng, S-C. \& Kuo, C-M., 2004, 'Employee relationship and knowledge sharing: A case study of a Taiwanese finance and securities firm', Knowledge Management Research \& Practice 21, 24-34.

Lightner, R., Benander, R. \& Kramer, E.F., 2008, Faculty and Student Attitudes about Transfer of Learning, viewed 10 March 2009, from http://www.insightjournal. Transfer of Learning, viewed 10 March 2009, from http $/ / \mathrm{h}$
net/Volume3/FacultyStudentAttitudesTransferLearning.pdf

Lindquist, D., Denning, T., Kelly, M., Malani, R., Griswold, W.G. \& Simon, B. 2007, 'Exploring the Potential of Mobile Phones for Active Learning in the Classroom', paper presented at the Technical Symposium on Computer Science Education Conference, Kentucky, USA, March 07-11, 2007

Major, E.J. \& Cordey-Hayes, M., 2000, 'Engaging the business support network to give SMEs the benefit of foresight, Technovation 20(11), 589-602.

Mellow, P., 2005, The media generation: Maximise learning by getting mobile, viewed 15 June, 2011, from http://www.learningdirectorsnetwork.com/refdocs/ Maximise_Learning_by_Getting_Mobile.pdf

Moteleb, A. \& Woodman, M., 2007a, 'Notions of Knowledge Management Systems: A Gap Analysis', Electronic Journal of Knowledge Management (eJKM) 5(1), 55-62.

Myers, M.D., 1997, 'Qualitative Research in information Systems', MIS Quarterly 21(2), 241-242.

Nonaka, I., \& Takeuchi, H., 1995, The Knowledge - Creating Company: How Japanese Companies Create the Dynamics of Innovation, Oxford University Press, Oxford, UK.

Nonyongo, E., Mabusela, K. \& Monene, V., 2005, 'Effectiveness of SMS Communication between University and Students', paper presented at The 4th Conference on Mobile Learning, Cape Town, South Africa, October 25-28, 2005. 
Olikowsky, W.J. \& Baroudi, J.J., 1991, 'Studying Information Technology in Organisations: Research approaches and assumptions', Information Systems Organisations: Researc
research 2(1), 1-28.

Palen, L., 2002, 'Mobile Telephony in a connected life', Communication of the ACM, 45(3), 78-82.

Pollack, J., 2006, The New Media Landscape: 2006, viewed 23 August 2008, from http:// newmedialandscape.com/e107/e107 files/downloads/pmc/PMC 02.06.2006.pdf

Pousttchi, K., Turowski, K. \& Weizmann, M., 2003, 'Added value-based approach to analyze electronic commerce and mobile commerce business models', in R.A.E. Andrade, J.M. Gómez, C. Rautenstrauch \& R.G. Rios (eds.), Proceedings of the International Conference of Management and Technology in the New Enterprise, La Habana, April 22-25, 2003, pp. 414-23.

Prensky, M., 2004, 'What can you Learn from a Cell Phone? Almost Anything', Paper presented at The 4th Conference on Mobile Learning, Cape Town, South Africa, October 25-28, 2004.

Roto, V., 2006, Web Browsing on Mobile Phones- Characteristics of user experience, unpublished doctoral dissertation, viewed 22 September 2008, from http://www. lib.tkk.fi/diss/2006/isbn95/2284707/isbn95122847071.pdf

Sarker, S., Sarker, S., Nicholson, D. \& Joshi, K., 2003, 'Knowledge transfer in Virtual Information Systems Development Team: an Empirical Examination of Key Enablers', papers presented at The 36th Hawaii International Conference on Systems Science, Big Island, Hawaii, USA, January 6-9, 2003.
Schindler, M. \& Eppler, M.J., 2003, 'Harvesting Project knowledge: A review of project learning methods and success factors', International Journal of Project Management 21, 219-228.

Sharples, M., 2005, 'Learning As Conversation: Transforming Education in the Mobile Age', in Proceedings of Conference on Seeing, Understanding, Learning in the Mobile Age, Budapest, Hungary, April 28-30, 2005, pp. 147-152.

Sharples, M., Taylor, J. \& Vavoula, G., 2005, 'Towards a Theory of MobileLearning', in $\mathrm{H}$. van der Merwe \& T. Brown, Mobile Technology: The Future of Learning in Your Hands, mLearn 2005 Book of Abstracts, 4th World Conference on mLearning, Cape Town, 25-28 October Cape Town: mLearn 2005, p. 58, viewed January 15, 2008, from http://www.mlearn.org.za/CD/papers/Sharples-\%20Theory\%20 of\%20Mobile.pdf

Sternberg, R.J., Wagner, E., Williams, W. \& Horvath, J., 1995, 'Testing common sense', American Psychologist 50(11), 912-927.

Strahilevitz, L.J., 2004, A social networks theory of privacy. The Law School, University of Chicago. The Social science research network electronic paper collection, viewed 05 January 2008, from http://ssrn.com/abstract_id=629283

Szulanski, G., 1996, 'Exploring Internal Stickiness: Impediments to the transfer of best practice within the firm', Strategic Management Journal 17, 27-43.

Wagner, E.D., 2005, Enabling Mobile Learning, viewed 15 June 2011, from http://net. educause.edu/ir/library/pdf/ERM0532.pdf

Walliman, N., 2006, Social Research Methods, Sage Publications, London, UK. 